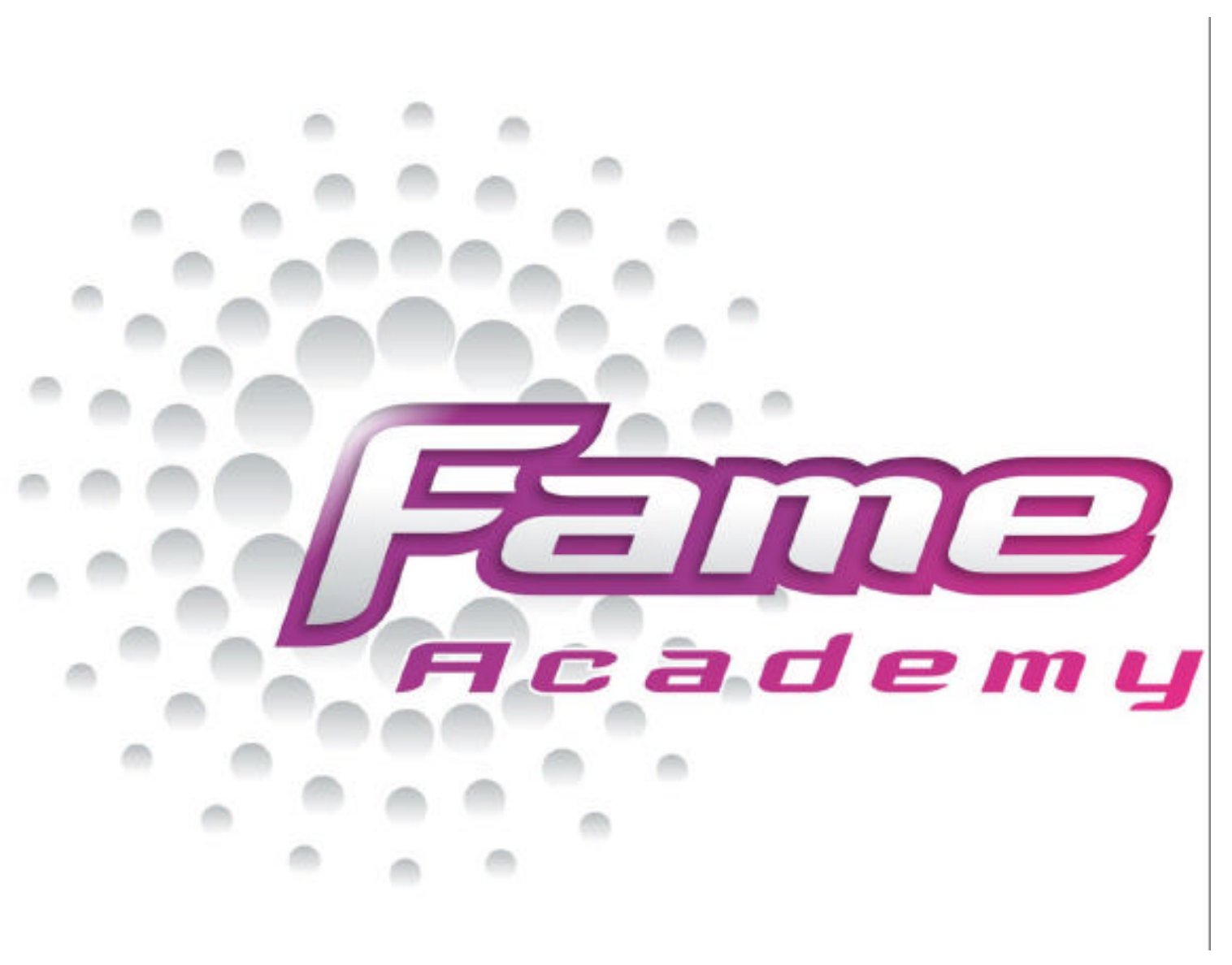




\section{THE ACADEMY}

\section{Witanhurst House}

Set in 5.5 acres atop Highgate Hill, the spectacular £35 million Grade 2 listed Academy has hosted both royalty and musical virtuosos since it was completed in the early 1920's.

Queen Elizabeth II has danced in the ornate ballroom, Yehudi Menuhin has played there when he was a houseguest and the BBC recently filmed TIPPING THE VELVET there.

The Academy's neighbours include Sting, Boy George, and George Michael. Previous neighbours have included Samuel Taylor Coleridge, and J.B. Priestly.

\section{Inside the Academy...}

The Academy is powered by 850 kilowatts of power, enough to boil half a million kettles at any one time

There is 72 miles of cabling, enough to stretch all the way from the Academy to Brighton

The action at the Academy is followed on 467 television monitors. Stacked on top of each other, they would be taller than Big Ben

The students of the Academy are heard using 340 channels of sound, filtered and recorded through 12 sound desks

The students are monitored by 49 cameras, weighing a total of $900 \mathrm{~kg}$

There are a total of 84 microphones dotted around the Academy

The Academy is lit up using 1570 lightbulbs. That's enough to light up nearly 100 average modern homes.

Over 1000 cups of tea are consumed each day at the Academy. 


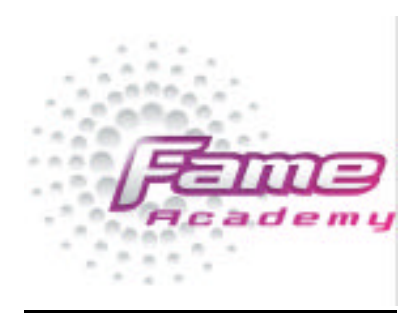

\section{Summary of Rules for Students}

The Academy is a centre of excellence for the students voted in by the public. It is a residential establishment with six teachers and includes performance rooms, a dance studio, communal living room and shared bedrooms for students.

The Academy is run by the following staff: a Head Teacher, 2 Vocal Coaches, a Fitness Coach, a Music Teacher and a Personal Tutor.

If students break the rules, the Head has the discretion to impose disciplinary measures including, in extreme cases, expulsion.

The rules include:

Morning wake-up at $7.30 \mathrm{am}$, lights out at $11 \mathrm{pm}$.

Attendance at all the Academy's classes and personal development periods is compulsory and lateness will not be tolerated.

Smoking is not permitted anywhere inside the Academy building. If the Head deems it to be in the interest of a student's health and quality of performance, they may be asked to stop smoking.

At the discretion of the Head, small quantities of alcohol may be available to students with their evening meal or on special occasions.

The Personal Tutor is available to students as their guardian, friend and counsellor. His door is open at all times. The Personal Tutor does not take part in teaching, nor in the decisions about who should be put on probation.

Students will be allowed one phone call a week, the duration of the call to be decided by the Academy.

Students may receive fan mail, which will be vetted by the teachers and distributed to the students.

A laundry service will be provided. Students must ensure that each item of clothing, including underwear, must be clearly labelled with their names. 


\section{STUDENT TIMETABLE}

7.30AM

$8.30-10.00$

10.00

$10.00-11.30$

$11.30-13.10$

$13.10-14.00$

$14.00-15.30$

$15.30-16.30$

$16.30-19.00$

$19.00-20.00$

$20.00-22.30$

23.00
WAKE UP

FITNESS WITH KEVIN IN THE DANCE STUDIO

SHOWERS

FREETIME

VOCAL COACHING AND STAGING WITH CARRIE AND DAVID.

LUNCH IN THE DINING ROOM

SHOW RUN THROUGH IN THE DANCE STUDIO

INCLUDING SURVIVAL SPEECHES FOR THOSE ON PROBATION

PERSONAL DEVELOPMENT PERIOD / STAFF MEETING IN THE HEADS OFFICE

FREETIME

DINNER IN THE DINING ROOM

GROUP SONGWRITING

LIGHTS OUT 


\section{Fame Academy on BBC THREE}

Claudia Winkleman presents insights into life at the Academy and will be the first to interview the expelled student who walks off stage and straight into the BBC THREE studio.

All the teachers will be dropping in for in-depth chats about the students and giving candid opinions on their progress.

Claudia will also be joined by celebrity guests and specialists to dissect goings on. And viewers will be involved at every step by phone, text and email.

BBC THREE viewers will see the heart rates of the students race as they cast their votes on showdown night illustrating just how hard it is to have your future existence at the Academy in the hands of your peers, and how tough it is to have to send a 'friend' out of the Academy, by voting against them. 


\section{m \\ CBBC At The Fame Academy}

Jake Humphrey and Holly Willoughby have the best view of goings on at the Academy from the CBBC studio situated in the garden.

Every day they will report live on what the students are up to. CBBC viewers will follow the students through their timetable from the moment they wake up to the last thing they do at night, with all the exercise classes, vocal warm ups and song writing sessions in between.

Academy teachers will visit the CBBC studio daily to give the low-down on how the students are progressing, and there will be a weekly headmaster's report from Richard Park.

There will be daily vox pops from CBBC viewers to find out what they think about the students and the teachers and the chance for viewers to ask the questions that matter to them, give messages of support to those on probation - and of course comment on the tutor's opinions.

CBBC viewers will be invited to write fan mail that can be delivered to the Academy students via their pigeonholes. There will also be loads of competitions to enter with fabulous prizes, including the chance to come to the Academy and report backstage from the live Showdowns.

\section{CBBC FACTS}

Fame Academy on CBBC reached 4.6 million children ( $50 \%$ of all children) over the ten weeks.

Amongst the whole audience (aged 4+) the 5-minute episodes of Fame Academy on BBC ONE had an average share of $11 \%$ and average audience of $1,306,000$.

Amongst 4-15 yr olds they had a $24 \%$ share and average audience of 527,000 .

Repeat episodes on BBC TWO in the mornings took an overall share of $13 \%$ and average audience of 727,000 and amongst children the share was $30 \%$ and average audience 466,000

On The CBBC Channel episodes took an average share of around $1 \%$ which was on a par with The Channel average at the time, so quite good. Ratings peaked as high as a $4 \%$ share.

Around 5 million children saw at least 3 minutes of CBBC At The Fame Academy across all the different programmes. 


\section{CAT DEELEY}

\section{Presenter}

\section{Biography}

Cat currently presents CD:UK every Saturday morning and includes an hour long chart show featuring live performances, videos and exclusive interviews. Previously she co-presented on SM:tv Live with Ant \& Dec. The show includes 3 hours of live television along with Celebrity interviews, comedy sketches and live music.

She has just finished presenting the a prime time ITV1 series STARS IN THEIR EYES: KIDS which achieved fantastic ratings.

Earlier in the year she presented COMIC RELIEF DOES FAME ACADEMY with Patrick Kielty, who she also presented FAME ACADEMY with in 2002.

Cat co-presented a weekly show on MTV called HIT LIST with Edith Bowman with whom she also presented Cat and Edith's HIT MUSIC SUNDAY on Capital Radio.

Cat flew out to New York to host an Elton John Special for ITV, where the British public voted for their top 10 songs to be performed live.

Cat was at the helm on many of MTV'S show including several series of the fashion show STYLISSIMO and coverage of the channel's own awards ceremonies, along with live events GIRLS R US; SELECT; WEEKEND EDITION; THE END OF THE YEAR SHOW; THE TURN ON; TUNE IN, CHILL OUT WEEKEND and DANCE FLOOR CHART. She is proving to be a flexible talent, playing an active role in the writing and research of the shows. Other solo presented programmes for ITV include THE LATIN GRAMMIES; WISH YOU WERE HERE; EMA AWARDS; PARTY IN THE PARK and her own show DEELEY DOES featuring WESTLIFE.

So far Cat has won the Body of the Year from Nivea, Woman of the Year and Presenter of the Year 2001 from Maxim and numerous awards for SMTV:LIVE and CD:UK along with Ant and Dec, these include: an RTS award; The People's Choice Award at the Comedy awards; TV QUICK Award; BRIT AWARD (for CD:UK)and a CHILDREN'S BAFTA. Most recently Cat won a BAFTA for Best Presenter. 


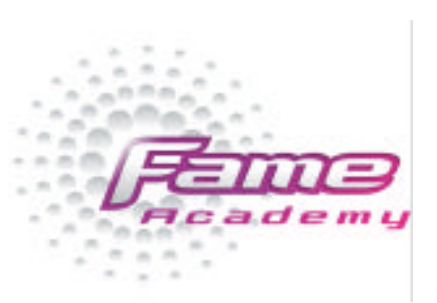

\section{PATRICK KIELTY}

\section{Presenter}

\section{Biography}

Patrick is currently presenting his own BBC ONE chat show PATRICK KIELTY ALMOST LIVE on Friday nights, which is now in its sixth series. Earlier in the year he presented COMIC RELIEF DOES FAME ACADEMY with Cat Deeley, who he also presented FAME ACADEMY with in 2002.

Patrick Kielty studied psychology at Queen's University in Belfast, during which time he co-opened Belfast's first stand-up comedy club The Empire spawning a one-off BBC television special THE EMPIRE LAUGHS BACK, RTS Award winner.

Other early television appearances include LOOSE TALK (BBC TWO) and THE STAND-UP SHOW (BBC ONE). In 1993, Patrick presented the teenage magazine show SUS TV for UTV, and in 1995 he presented the Northern Ireland part of COMIC RELIEF, sharing the stage with top names such as Jo Brand and Lenny Henry.

Patrick earned huge acclaim in Northern Ireland, hosting his own live show PK TONIGHT, which attracted a $60 \%$ audience share on BBC Northern Ireland! The programme also won him an RTS Award for 'Best Regional Presenter'.

His first network prime-time show followed when he hosted AFTER THE BREAK for BBC ONE.

Patrick became a household name in the UK with Channel 4's LAST CHANCE LOTTERY. He then went on to present BBC ONE's Saturday night programme THE NATIONAL LOTTERY BIG TICKET with Anthea Turner and hosted the first series of PATRICK KIELTY ALMOST LIVE (Green Inc for BBC TV).

In 2001 Patrick had a cameo role on BBC Northern Ireland's GIVE MY HEAD PEACE, asked the 'Question of the Week' for Ch4's THE PRIORY (Ginger Prods), co-presented THE BIG BREAKFAST (Planet 24 Prods for Ch4) and enjoyed guest appearances on PARKINSON (BBC1), IT'S ONLY TV...BUT I LIKE IT (Open Mike for BBC TV), THEY THINK IT'S ALL OVER (TalkBack for BBC1), HEAD ON COMEDY (BBC TV), QUESTION OF POP (BBC TV) and I LOVE THE 1980s (BBC TV). 
In the summer of 2001 Patrick went live on BBC ONE with his topical Friday night chat show PATRICK KIELTY LIVE from Belfast (Green Inc). And in March 2002 Patrick hosted a new BBC TWO betting quiz show STUPID PUNTS (CHX Productions) and had just finished the second series on BBC Three. 


\section{CLAUDIA WINKLEMAN}

\section{Presenter - BBC THREE}

\section{Biography}

Claudia currently presents BBC3's flagship programme LIQUID NEWS and has appeared on NEVER MIND THE BUZZCOCKS on BBC TWO.

In 2001 she presented a six part documentary series for BBC Choice TOILETS produced by Tiger Aspect Productions and hosted the first series of FAN-O-RAMA, a studio based panel show for E4, produced by Channel X.

She has presented CENTRAL WEEKEND LIVE, a live topical studio discussion show for Carlton Television and BBC ONE's HOLIDAY programme where her wicked sense of humour and ascerbic tongue earned her her own spin off programme - an hour long prime time special which took her around the world in 34 days reporting from Japan, India, Costa Rica and Dubai.

Claudia is a regular travel writer for the Sunday Times, Independent and Metro and is a regular contributor to Cosmopolitan.

Claudia graduated from Cambridge University with an MA Hons in History of Art.

Her first child, Jake was born in March 2003. 


\section{(ams}

\section{RICHARD PARK}

\section{Fame Academy Head Teacher}

\section{Biography}

Richard Park was voted 'Most Influential Person in the Music Industry' by Record and Radio Executives in 2001 before becoming Head Teacher in FAME ACADEMY in 2002.

As Programme Controller at Capital Radio Richard hired Neil Fox, Pete Tong, Tim Westwood and Jakki Brambles.

Richard has also been Director of Wildstar Records since 1996, responsible for signing Craig David amongst other British stars.

The Richard Park Consultancy opened in 2001 as a cross-media company working with TV, Radio, Press, Advertising Agencies and the Record Industry.

In 2002 Park Management launched representing artists, writers, producers and jingle writers. Park Records, a joint venture with Universal Music, followed in 2003.

Richard began his career as a reporter on his local newspaper, the Fife News, before his first job in radio as a presenter with both BBC Scotland and BBC Radio 1. In 1974 he became presenter of music and sport at Radio Clyde and branched into other areas of the media during the mid-70s with a column in the Scottish Daily Express and presenting jobs on Scottish Television.

Richard became Head of Entertainment and Sport at Radio Clyde before joining Capital in 1987. During these years, he won many awards including Sony Broadcaster of the Year in 1983; Best Sports Presenter at the New York Radio Festival in 1984; and Scottish Radio and TV Programme of the Year in 1985.

On joining Capital, Richard was responsible for developing the station into two separate outputs - Capital FM and Capital Gold. He also launched the first annual awards lunch in aid of Help A London Child. He was appointed Director of Programmes for the Capital Group of stations in 1994.

He was made a Fellow of the Radio Academy in 1993 and the following year was awarded the IMF British Music Roll of Honour to recognise his 
outstanding contribution to British music. Between 1998 and 2001, Richard was also Chairman of the Prince's Trust 'Party In The Park' committee. 


\section{(2)}

CARRIE GRANT

\section{Fame Academy Vocal Coach}

\section{Biography}

Carrie Grant has been working as a vocal coach and producer for many years teaching artists such as Take That, The Spice Girls, and more recently S Club, Mel C., Atomic Kitten, Will Young, Victoria Beckham, Amy Studt, Ashley Hamilton, Emma Bunton, S Club 8, Charlotte Church and numerous others. She is often called upon to coach artists throughout the US and Europe, in the recording studio, TV and live concerts.

Her work as a vocal coach has been widely recognised through her work on FAME ACADEMY, COMIC RELIEF DOES FAME ACADEMY and POP IDOL.

Carrie has also been a top session singer for many years, working with artists such as Diana Ross, Roberta Flack, Rod Stewart, Lighthouse Family and Fat Boy Slim. She has also recorded as an artist in her own right and along with her husband, David, they won the prestigious MOBO Award for best gospel album for "Watching and Waiting" in 1998.

Prior to this Carrie has had many roles in the entertainment industry as an artist, dancer and a presenter for various television programmes including HOW DARE YOU (Tyne Tees), FREEZE FRAME, and the BBC's award winning series HEART AND SOUL. In fact it was whilst presenting that she met up with her partner David, who was performing on the show as lead singer of Brit-funk duo LINX, and will be vocal coach alongside her in the new series of FAME ACADEMY.

Carrie will soon be seen fronting an exciting new programme for CBBC - THE AGENTS - where she will oversee children as they promote and develop the entertainment careers of a selected child from their school. She has already presented some 40 radio programmes for BBC education this year. 


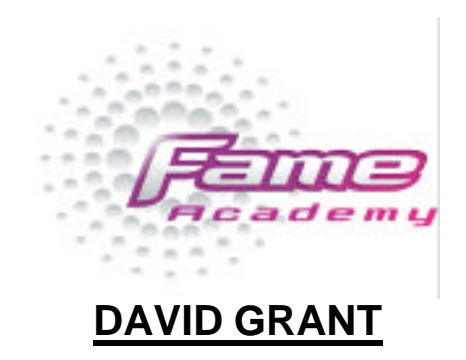

Fame Academy Vocal Coach

Biography

David Grant is the new member of the Academy staff and is vocal coach alongside his wife Carrie after appearing on COMIC RELIEF DOES FAME ACADEMY.

David began his career as a performer with 80 s band LINX. The band, which was primarily a partnership between vocalist David and bassist Sketch, were at the fore of Brit-Funk with four top twenty singles YOU'RE LYING, the classic INTUITION, THROW AWAY THE KEY and SO THIS IS ROMANCE coupled with two very successful albums, the silver status INTUITION and GO AHEAD.

The band split in 1983 and David re-emerged as a solo artist with a string of hit singles STOP \& GO, WATCHING YOU WATCHING ME and LOVE WILL FIND A WAY which formed the basis of his successful solo album DAVID GRANT.

David's next successes came from a partnership with Jaki Graham that produced their massive hit single COULD IT BE I'M FALLING IN LOVE which took them to number 5 in the charts and was quickly followed with another big hit single - their version of Todd Rundgrenn's MATED.

Further successes followed with David's CHANGE album on Polydor and the critically acclaimed ANXIOUS EDGE album on Fourth \& Broadway that contained the club smash KEEP IT TOGETHER. Throughout this period David was also busy writing hits for other artists including the US smash ONE STEP CLOSER TO YOU for Gavin Christopher, Hot Chocolate's HEARTAHCE NO 9 and another big US hit with IF YOU WERE MINE for Cheryl Lynn. He also found time to present TV shows such as RIVERSIDE, CDQ as well as being virtually a resident on Mike Read's POP QUIZ.

In the mid 90's David and his partner Carrie made their highly acclaimed album WATCHING AND WAITING that went on to win them a prestigious MOBO Award for Best Gospel Album in 1998. David also found time to develop an acting career, performing at the National Theatre and the Bristol Old Vic as well as for Channel 4 films.

Having performed as a vocalist, and also recorded on countless sessions as a session vocalist, David has put his experience into practice as a vocal coach 
appearing on COMIC RELIEF DOES FAME ACADEMY and POP IDOL as well as working with numerous of the UK top artists including Will Young and Gareth Gates, whom he also coached through their UK tour, S Club, S Club 8, Take That and The Spice Girls. 


\section{Perom \\ Academe}

\section{KEVIN ADAMS}

\section{Fame Academy Fitness Coach}

\section{Biography}

Kevin Adams has been at the pinnacle of his career for many years and is one of the most respected choreographers in Europe. His range of styles includes Street, Ballet, Jazz, Tap, Locking, Body Popping, Breakdance, Ballroom, Salsa, Pas de Deux, Yoga, Aerobics, Personal Training and Contemporary.

In dance terms, there is nothing this man has not done, including training Ruby Wax, Ulrika Jonsson and John Thomson in COMIC RELIEF DOES FAME ACADEMY in March 2003.

Over the last ten years, he has been the UK and European aerobics champion - as well as being $4^{\text {th }}$ in the World rankings; trained extensively with Paula Abdul in Los Angeles and worked with a truly extraordinary number of artists.

These include Mariah Carey for her 'Honey' album launch; Cher for 'Strong Enough' and her Brit Awards performance of 'Believe'; Steps' sell-out 'Steptacular Tour'; Denise Van Outen for her 'Something For The Weekend' series; Louise for her 'Naked' video; Boyzone's 'Where We Belong' tour; The Spice Girls' Brit Awards performance where Kevin appeared as a dancer; and Eternal for performances at Party In The Park and the Smash Hits Poll Winners' Party.

He has recently worked with Helen Adams from Big Brother 2 on her fitness video and Jade Goody from Big Brother 3. 


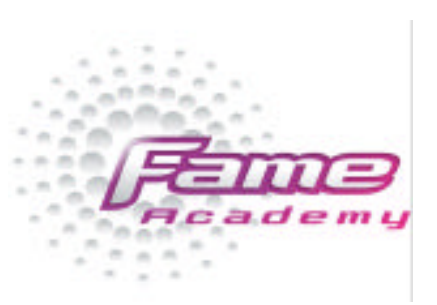

\section{JEREMY MILNES}

\section{Fame Academy Personal Tutor}

\section{Biography}

Jeremy has recently presented BBC Three's THE BACHELOR after his success in FAME ACADEMY in 2002. He is also the presenter of THE TEST (ITV) and co-presents WOULD LIKE TO MEET on BBC TWO with Jay Hunt and Tracey Cox.

Other recent television appearances include TEST THE NATION (BBC ONE), THE HONEY TRAP (CH4), DANGERZONE (BBC ONE) and THE WEAKEST LINK (BBC TWO).

Jeremy is a trained actor, drama teacher and communication, confidence and assertiveness tutor as well as a qualified Samaritan Listener. Acting credits include the lead male role in the film THE VAPOUR TRAIL, various television appearances including THE BILL and 99-1 with Leslie Grantham and numerous roles with touring theatre companies.

He has appeared in a number of TV commercials all over the World including a prestigious Perrier Water commercial directed by Ridley Scott.

Corporate work included films for Thorn EMI, Lombard Tricity, and most recently hosting and presenting a conference and awards for Brook Street at the ICC in Birmingham.

Jeremy is a graduate from the University of East Anglia. He began his career by jetting out to Sri Lanka to work with the British Council teaching drama and theatre to local teachers. On returning, Jeremy became Head of Drama at Willesden High School in North London. At the same time, he auditioned for a series of acting jobs and soon joined the Molecule Theatre Company.

He has also been a learning mentor at Quintin Kynstan School in St John's Wood. 


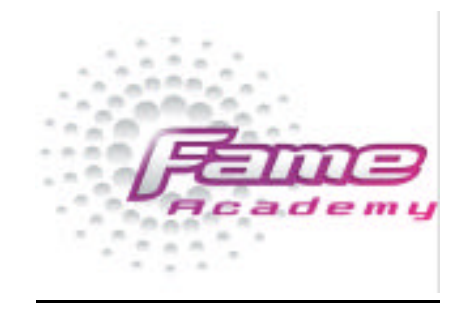

\section{JO NOEL}

\section{Fame Academy Music Teacher}

\section{Biography}

Jo has been learning and performing music since the age of 3 and has an Honours Degree in Music from Elder Conservatorium, South Australia.

She has worked professionally in the music and entertainment industry for the past 15 years, working as a musician, composer, conductor, arranger, vocal coach, singer, producer and director.

As a Music Coach, Jo has worked with many artists including 911, Spice Girls, Mel B, and Damage as well as being Music Teacher for FAME ACADEMY, COMIC RELIEF DOES FAME ACADEMY and German Pop Idol Tour.

Jo has performed with artists such as Sting \& M People, and at every major venue, including the London Palladium, the Royal Albert Hall and Wembley Arena.

In addition to teaching, Jo regularly acts as a consultant in musicianship and singing at various performing arts colleges and theatre companies. 


\section{mon \\ HOLLY WILLOUGHBY \\ Presenter CBBC \\ Biography}

Holly is currently co-presenter of $X$-CHANGE on the CBBC Channel and is also filming CBBC's CALL THE SHOTS.

She presented CBBC's coverage of the first series of FAME ACADEMY and co-presented COMIC RELIEF DOES FAME ACADEMY with Jake Humphrey.

In 2002 Holly filmed a brand new series XPERI-MENTAL for CBBC which aired in January 2003.

Holly got her first job in TV when she accompanied a friend to a casting and got picked out herself by 19 Management who were looking for a team of young presenters to host their new Saturday morning show S Club TV.

Holly's talents also lie with acting and she has recently starred in S Club 7's LA 7.

At 14 Holly was discovered by Storm Modelling agency whilst on a school trip. In just a few years she had been the face of Rimmel, body of Pretty Polly and appeared on the cover of various women's magazines. Holly has appeared in numerous TV commercials and it was from this that she decided TV presenting was the job for her.

Since then Holly has co-hosted 13 episodes of S CLUB TV as well as appeared on SMTV, CITV and presented an award at the TV HITS AWARDS. Earlier this year she filmed a pilot for Initial Productions CLUB CULTURE that saw her hosting a show from inside a nightclub for under 18's!

In the midst of all her work Holly is studying a Psychology Degree with Open University. 


\section{JAKE HUMPHREY}

\section{Presenter CBBC}

\section{Biography}

Jake is one of the main presenters on CBBC ONE and the CBBC Channel and co-presented COMIC RELIEF DOES FAME ACADEMY with Holly Willoughby in March 2003.

He recently presented numerous major live events including PROMS IN THE PARK and CBBC GOLDEN JUBILEE PARTY.

Jake's first job was as a DJ with Hospital Radio Norwich before becoming a runner for Rapture TV. He then made his move into presenting and has presented a huge range of programmes including the first reality programme for children called RULE THE SCHOOL in 2002 for BBC Scotland CBBC ONE - this was CBBC's highest rating show of summer 2002.

Jake also presented on Against All Odds for BBC Scotland filming behind the scenes on productions involving dangerous stunts and reconstructions. This led to him becoming the main presenter for $A A O$, as well as presenting a new strand entitled JOBS FOR JAKES that involved intensive training with the Police, Paramedics, Red Cross, and Lifeboat rescue team.

Since 1999, Jake has presented radio music and chat shows, Internet based sport channels and an eight-hour live OB from Board-X Snowboarding and Skating, 1999. He has worked on BBC LEARNING ZONE projects, GAMERS for Rapture TV, BYTE ME for Rapture TV and ITV and presented 26 episodes of the live youth show EXPOSURE on Sky TV. 


\section{Perome \\ $\rightarrow c a d \in m \in$}

\section{POLYDOR}

Polydor is the UK's leading record company, and home to some of the most successful new talent to emerge from this country in the past three years.

The label's UK signings include the platinum-selling new artists Daniel Bedingfield, Sophie Ellis Bextor and Ms Dynamite. They share a roster with successful acts from across the musical spectrum, from lan Brown to Yeah Yeah Yeahs to S Club 8. Its international roster includes some of the biggest and most exciting names in music, Eminem, 50 Cent, Limp Bizkit, Sting, Enrique Iglesias and Sheryl Crow among them.

Formed in 1946, Polydor is a label with a rich heritage. Its catalogue includes the work of such musical greats as The Who, Jimi Hendrix, Cream, The Jam, Bee Gees and Abba.

Polydor is run by joint managing directors David Joseph and Colin Barlow. It has been the number one record company in the UK for artist albums for each of the past four years. Polydor is owned by Universal Music, the world's leading music company with wholly-owned record operations or licensees in 71 countries around the world. 


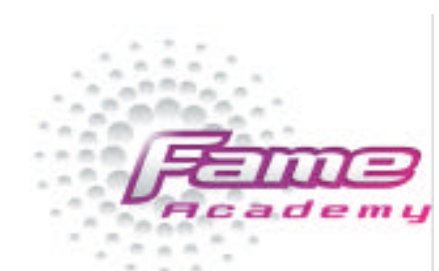

\section{INITIAL (PART OF ENDEMOL UK)}

Emmy Award winning INITIAL (part of Endemol UK) is producing Fame Academy for the BBC. The company has driven music and events programming in the UK and its programmes have been seen in over 100 countries.

It's portfolio of live events and music television include THE ORANGE BRITISH ACADEMY FILM AWARDS (BBC 1), PARTY IN THE PARK (Five), THE BRIT AWARDS 1993-2000 (ITV) and the recent worldwide webcast of JK ROWLING AT THE ROYAL ALBERT HALL for her record-breaking bestseller Harry Potter And The Order Of The Phoenix.

In October Initial is set to bring the worlds of fashion and music under one roof in an explosive international event - FASHION ROCKS (Channel 4). The company has also produced THE VOICE (Channel 4) - a landmark three-part special that journeys through the greatest vocal talents ever.

INITIAL also has a growing portfolio of popular documentaries including THE BIG FANTASY - coming soon on Sky One, and COSMOPOLITAN'S 50 WAYS TO PLEASE A MAN 50 WAYS TO PLEASE A WOMAN - a two part special for Five. Also for Five are three documentaries charting the stories behind this year's biggest summer blockbusters - The Hulk, Terminator 3 and Charlie's Angels 2.

INITIAL is also behind a slate of youth programmes including XPERIMENTAL for CBBC; THE ELIMINATOR (CITV) and the forthcoming reality entertainment series THE AGENTS (CBBC) featuring FAME ACADEMY vocal coach Carrie Gant. Previous youth credits include BBC 1's pop music dramas MIAMI 7 and LA 7 (featuring S Club 7) - which became the UK's number one kids' shows and were major international hits.

Over the years INITIAL has worked with nearly every major international music artist in the world - from Elton John, Madonna, David Bowie, Paul McCartney and Michael Jackson to U2, Robbie Williams and Travis.

The company is part of the ENDEMOL UK group - one of the UK's leading producers of entertainment formats for the worldwide market and behind some of the biggest hits to come out of the UK.

The group is dedicated to ideas that work across a variety of media and incorporates three other production arms - ENDEMOL UK PRODUCTIONS, 
BRIGHTER PICTURES and ZEPPOTRON. Other credits include the BAFTA winning productions of BIG BROTHER (Channel 4; E4). 